\title{
Sustainable Urbanization's Challenge in Democratic Republic of Congo
}

\author{
Misilu Mia Nsokimieno Eric (Corresponding Author) \\ School of Resources Management Studies, Institute of Earth Exploration and Information Technology \\ China University of Geosciences, Wuhan, 388Lumo Road, Wuhan 430074, Hubei, P.R. China \\ Tel: 86-137-2014-6319Ｅ-mail: miansoki@gmail.com \\ Professor Chen Shouyu \\ School of Resources Management, Institute of Earth Exploration and Information Technology \\ China University of Geosciences, Wuhan, 388Lumo Road, Wuhan 430074, Hubei, P.R. China \\ Professor Zhang li Qin \\ School of Environmental Studies, Institute of Land resources Management \\ China University of Geosciences, Wuhan, 388Lumo Road, Wuhan 430074, Hubei, P.R. China
}

\begin{abstract}
In the context of rapid urbanization in Democratic Republic of Congo, overpopulation in Kinshasa's city increasingly carries out chaos, inequalities, poverty, environmental degradation, open spaces loss, socio economic tension, and spontaneous settlements and sprawl. This rapid urban growth occurs without planning and productive employment compounded by weak government involvements. These crisis situations put to the forefront sustainable urbanization as a priority issue for urban development with reference to the globalization and technology. This requires reconsidering urbanization process to stimulate economic growth and mobilize resources at local, national and global levels. A comprehensive reform based on an integrating vision of governance and collective commitment to manage efficiently natural resources. The paper reviews pragmatic approaches in urban planning decision in its whole refers to the dynamics of management, qualification and transformation of the city. The paper presents urban renewal as remedial action holding opportunities to improve environmental quality.
\end{abstract}

Keywords: Sustainability, Sustainable urbanization, Urban planning, Urban renewal

\section{Introduction}

Since the latter century, urbanization with unprecedented urban growth exacerbates problems in environment, human settlements, infrastructures, and socio - economy in cities in Democratic republic of Congo. It is observed an increasing ceaseless chaos, deficits in housing, basic services, and water and electricity supply ;environmental degradation, informal sector, infrastructures deterioration, insalubrities, loss open spaces, overcrowding, poverty, squatters and slums settlements, social tensions, traffic congestion, unemployment and underemployment, unplanned sprawl, and wastes.

Today, with an estimation at more than 10 million of people in the Kinshasa's city (United Nations, 2007), the country is very limited in capacity to stimulate economic growth, mobilize resources and provide the most basic services. Likewise, the latest decade conflict armed and the constant insecurity in the east of the country accelerate the rapid urban growth with a massive immigration of ten thousands people. The country is ill equipped to meet urban challenges of its growing populations in urban areas, as most Sub Saharan countries African. The situation reflects the socio - economic system in decline. Nelson Mandela, South Africa's former President, has noted that Sub-Saharan Africa is the only region in the world where urbanization is associated with negative economic growth (cited in Harsch 2001: 1). It was already revealed at $72 \%$ the urban population living under slum conditions in Sub Saharan Africa (UNFPA, The State of World's Population Report, 2007).

Presently, a greater number of urban populations live in squatter and slum settlements without electricity, hygiene, safe water, and also exposed at any kinds of risks in Kinshasa. The informal settlements swell on agricultural, forest, railways and rivers areas, or in high-risk zones such as steep, hill slopes, deep gullies and flood-prone. This leaves trail catastrophes of electrocution, erosions, floodwaters, landslides, and loss public spaces. The weak government structures compound a chronic anarchism and disorder in land use management, reduces urban governance to almost nothing. Obviously, the urban crisis situations reach its paroxysm. These involve losing quality of communications, education, employment, environment, health, and energy supply; the loss of open spaces, the loss of urban habitat conservation to historic preservation. Kinshasa's city is far from to achieve sustainable development.

For most of analysts, sustainable urbanization's challenge is a prime concern in Democratic Republic of Congo. Sustainable urbanization seeks to pursue growth and human development in harmony with protection of environment quality. It seems to be a genuine effort to reconsider urban planning in its multidisciplinary nature based on an integrating vision of urban issues, for land resources management with due regard for the ecology, and economic progress with social equity. 
How sustainable urbanization can be used to improve the quality of life? What are the strategic and operational choices and priorities that would enable for Democratic republic of Congo to gain the best in the process of urbanization? How sustainable urbanization planning can support positively urban growth and sprawl? What are the advantages and opportunities in Democratic Republic of Congo if this requirement is met?

The paper examines the context in which urban growth takes place in Kinshasa. It identifies the common urban problems facing most large cities in Democratic Republic of Congo. It further adopts and adapts international approaches to success sustainable urbanization, with a particular focus on Kinshasa's city. The paper explores the impact of reform policy and the urban renewal as a part of urban planning creates opportunities to give city a new image with due regard to balance economy and ecology. This is a crucial engine that guides urbanization towards sustainable growth .Importantly; emphasis will be placed on what is working and why it is working.

\section{Urbanization in the world}

\subsection{Urban World}

Certainly, Urbanization represents the movement of people from rural areas to urban areas with population growth equating to urban migration (United Nations). Historically; urbanization began with the Industrial Revolution. This was accompanied by the creation of jobs in cities and the reduction of people's proportion needed in farmlands. The first industrial revolution in Britain was accompanied by the growth of rapid urbanization (Williamson, pgs.241-242). As technology progress and farming give way to factories, rural life likewise give way to city life.

World urban growth was fastest in the mid $20^{\text {th }}$ Century, slowing gradually as more and more parts of the world have made the shift from being predominantly rural to predominantly urban. Before 1800, cities not exceeded one million of populations. As far back as 1900, the number and size of large cities has risen progressively as well as the proportion of urban population can reach or surpass one million of inhabitants within cities. Available figures illustrate the unprecedented world's urban growth from 220 million (13\%) in 1900 to 732 million in 1950 , to 3.2 billion in $2005,(49 \%)$; the global proportion of urban population almost fourfold since 1950(1). It is estimated that the world's urban population recently surpassed $50 \%$ of the total population in 2008 , that is to say the majority of people worldwide live in cities, for the first time in history (2).

The former Secretary-General of the United Nations, Kofi Annan, already approved this fact by saying; the world entered an urban millennium. Urbanization increases the concentration of population in cities with an impressive wave of urban growth that makes cities becoming larger. Developed countries were already far more urban than less developed countries with a higher rate of urban growth estimated at 75\% in 2000. Apparently, their degree of urbanization generally reflects their economies stability and wealth although it varies across the regions, In 1950, their ratio of urban growth already reached 53\%, unlike in the less developed regions, the prospects argue that the ratio of $50 \%$ will be reached around 2019 (World Urbanization Prospects: The 2007 Revision).

Nowadays, the critical urban growth occurs in developing countries. There are more cities with more than one million people in Africa and Asia (especially in China and India).Between 2000 and 2030, urban population in Asia will double to 2.6 billion people; in Latin America and the Caribbean countries will rise to 609 million from 394 million while in Africa will almost threefold from 294 million to 742 million (UN Habitats 2003 report). By 2050, about 6 billion of the world's then 9 billion people will live in cities, with the greatest concentrations in cities so called developing nations (Bos et al. 1994; United Nations 1993).

The exceptional growth of many urban agglomerations in many developing countries is the result of a threefold structural change process: the transition away from agricultural employment, high overall population growth, and increasing urbanization rates (Grubler, 1994). In many third world cities natural population growth is the major contributor to urbanization, rural-urban migration is still an important factor (de Haan 1997). With this trend of growth, the number and size of large cities cannot stand still.

\subsection{Migrations of People}

Migrations of people are the process of people's movements from one location to another place. City symbolizes a place with large, dense, and heterogeneous, or varied populations for creativity, innovation, and global economy. A key determinant of migration is the income differential between rural and urban regions (Gilbert and Gugler 1992).Obviously, cities ensure access to economy, education, energy, good health system, jobs, transport, housing and shelters, and higher security and living standards. In opposition to, rural areas often face to the poor market, infrastructure and the lack of supporting institutions for agriculture (credits for farmers).

This supports rural people to desert the farmlands and heading that are dominating and deteriorating quantity and quality of agricultural lands. These are the factors that push people out of rural areas to seek for a better urban life. So basically it comes down to people wanting to escape adverse rural conditions and take advantages of promptly the opportunities that are found in cities.

Internal migration is diverse, complex and constantly changing. It includes rural to urban, urban to rural, urban to urban, and rural to rural. On the other hand, international migration describes migrations of populations from one 
country to another country. In many cases, populations emigrate for social and economic opportunities. The gap between poor and rich countries is one of the main factors causing international migration. Cities in developed nations make advances to ensure goods jobs, peace security and political stability ; unlike developing countries having weak level of socio - economy , and unstable security to guarantee fundamentals utilities and social securities to its populations in urban areas.

In addition, poverty, injustice and armed conflicts increase the world's migrant population throughout the world. People (including refugees and internally displaced persons) and their families immigrate either to escape the poor socio-economic situation, or to flee oppressions and wars from their countries to rich countries where they think finding better conditions and opportunities to live and work quietly. The United Nations High Commission for Refugees (UNHCR) evaluated millions of people (more than 22 million people) were fleeing from domestic or international conflict in 199.In the past 30 years, the number of international migrants has more than doubled, to an estimated 191 million worldwide (3).

For all advantages relative to cities wherever located, emerging challenges seems to be a major concern worldwide. No doubt, poverty and sprawl sound as a bomb scare in the urban world.

\section{Urban Challenges}

\subsection{Urban poverty}

Indeed, rapid urbanization accelerates poverty in cities; it is estimated about $30 \%$ of the poor now live in urban areas but it is projected that the proportion will reach 50\% in 2035(World Bank,2002). Millions of people have not access to education, electricity health, foods, employment, income, sports, water, and activities; live in slums and exposed to diseases and violence and social conflicts.

Several United Nations agencies have estimated that on a global scale in year 2001 one billion people lived in poverty on consumption level below US \$1 per day, and 2.7 billion on less than US \$2 per day.

Poverty makes seriously the world unstable because of the wide gap between the two worlds. As a result, underdeveloped nations grow up their dependences on more developed nations.

A large proportion of Africans today live in absolute poverty. Increasingly, however, poverty is becoming an urban phenomenon and is growing rapidly (Satterthwaite, 1995: 3-10; Sparr, 1994). The causes of urban poverty are interlinked, stemming from such factors as employment insecurity, sub-standard housing, poor health, low levels of income generation, vulnerability to market shocks, and limited education (Becker et al, 1994; Amis, 1995; Moser, 1995; Wratton, 1995). Obviously, the declining economic performance of most African countries rise proportion of populations living below the poverty line in over-crowded slums and sprawling shanty towns around major cities. Estimates by UN-Habitat show that about $70 \%$ of all urban residents in sub-Saharan Africa live in slums (UN-Habitat 2003). Sub-Saharan Africa has some of the world's highest levels of urban poverty.

\subsection{Urban sprawl}

Urban sprawl is a pattern of unplanned, low density housing and commercial development outside of cities that usually takes place on previously undeveloped land (4). Urban sprawl is the dominant urban form in cities in Africa (United Nations report, 2007). Ordinarily, city enlarges around its peripheries along highways, roads, and rivers. It leads land consumption, lack publics space and community centers; problems in infrastructures, accumulation of constructions and the fragmentation of open spaces, disparities distribution of goods and economic resources. Furthermore, it increases traffic congestion and commute times, and weak disposal of energy are on increase. Urban sprawl is both a highly charged and critical issue because of enormous valuable and irreplaceable loss of natural areas, agricultural land, and ecologically sensitive habitats.

Moreover, the threats that sprawl causes to air and water quality as well as to biodiversity are emerging and very real. It becomes absolutely urgent to reconsider rapid urbanization in globalization as part of global economic forces.

\section{Globalization in the context of urbanization}

Today more than ever, the world is in global age. Globalization brings a strong economic, cultural, and technological interconnection between people and countries has been widely promoted as a process, which will improve the well being of both the developed and developing worlds (Horst et al.2001). Cities in developing countries can reduce poverty and stop chaotic urbanization with international cooperation. So, basically globalization creates new strategies dynamism in economic, political, and social that lead country reconfiguring beyond in its capacity. Cities are centers of innovation that shape or drive globalization finance, production, marketing, information, and knowledge production (Sassen, 1991; Gilbert and Gugler, 1992:64).Moreover, globalization supports development initiatives by ensuring also transfer funds, technology and capacities built. Internationals organisms (such as UN-HABITAT, UNDP, UNFPA, World Bank's, and others agencies)seeks to position development priorities on infrastructures by improving urban roadways, drainage, water supply, sewerage, and household garbage in Sub Sahara Africa. Effectively, globalization process reveals complex issues concerning the political instability, debt ridden with feelings of inferiority, aid dependency, and technologically backward less developed countries economies. Presently, Democratic Republic of Congo has not the capacity to function productively and sustainability in a sovereign manner, even if this capacity is increasingly compromised 
by global forces.

In addition, equally, poverty, climate change, and sustainable urbanization remain serious challenges where science and technology have a critical role to play. That suffices to say urbanization and globalization are interdependent. Knowledge possibilities and information technology opportunities in this context are the fundamental resources for city's development in developing countries. Information technologies applied in urban planning promote to understand and evaluate the process of urbanization for improving governance. In the context of urbanization, globalization complements with social progress brings advancements to both developed and less developed countries. Cities in developing countries can strive for sustainable development; by adopting techniques that aspire to the information technology. Geographic Information Systems (GIS) appears to be a tool to prevent unplanned sprawl towards urban development and the future cities.

\section{Geographic Information Systems (GIS) in urban planning}

Geographic information systems (GIS) have gained increasing recognition as an important tool for reaching sustainable resources management by cities. This new technology system is designed to identify potential of city as part of urban planning and to formulate development strategies in the daily operations of city. It is now joined to other methodologies of social and environmental assessment in a new set of techniques that meet the aims of sustainability. The management tools developed for exhaustive assessment of city into the urbanization process was developed as a land information system. GIS is commonly used as a tool to make simple urbanization process. City planning is an excellent application of GIS, in which common data is used to coordinate activities and reduce duplication of effort (Von Rimscha 1997).

People constantly want new things and want them a soon as possible often bringing on more changes. GIS include set of guiding principles that guide efforts to improve cities. By using GIS, the decision making process becomes much simpler with access to databases and information about cities. The databases often include demographic statistics (age, population density, etc.), many typical maps (roadways, water disposal, sewer systems, rivers, green spaces, forest, and equipments) traffic and zoning data.

Experts (urban planners, civil engineers, geographers, surveyors, etc.) can supervise their projects. They make plans, which set the standard for policy decisions of urbanization in a view of sustainable urbanization. GIS also allows visualizing present and future of the city, and performs the cadastral systems in a global land management perspective. Digital cadastral systems make easy an efficient land management as well as effective land-use administration and thereby, more generally, promote economic development, social cohesion and sustainable development. So, cities can dependably meet the requirements of local, state and international as well as special interest groups any times. The applications of GIS help largely solving real urban world problems.

\section{Urbanization in Kinshasa, Democratic Republic of Congo (DRC)}

\subsection{Overview}

The Democratic Republic of Congo (before called Zaire ) is the third largest land area in Africa after Sudan and Algeria; with a population estimated at $66,020,000$ (Wikipedia, the free encyclopedia).Its population represents the nineteenth most populous nation in the world. Potentially, DRC is one of the richest countries in natural resources (copper, cobalt, diamonds, gold, zinc, and other base metals). It has the second tropical forest in the world, and its wildlife has an exceptional biodiversity in the world, with fertile soils, ample rainfall, and considerable and varied mineral resources.

Urbanization as a global phenomenon occurs with the concentration of population in few large cities (Kananga, Kisangani, Lubumbashi, and Mbuji - Mayi) in Democratic Republic of Congo. Presently, these cities have more than one million of populations whereas Kinshasa remains the largest city, with more than 10 millions ,and it is expected to reach 20 millions by the year 2020(United Nations,2007).

\subsection{Urban Growth in Kinshasa}

The massive immigration began after independence, the urban population has jumped from 400.000 to more than 6 millions of people in 2001, and now the urban population is estimated at 10,076,099 (5). Nowadays, the armed conflict and constant insecurity in the east leads the immigration of displaced people at an impressive rate. This conflict is recognized as the deadliest conflict worldwide since World War II. Millions of populations displaced from their places to neighboring countries, and thousands of them arrived in Kinshasa to escape the war.

However, the urban growth does not correspond to the socio - economic conditions. The overpopulation is rapidly pushing city to shape the dominant form of city living based on expanding in all directions resulting in large-scale uncontrolled urban sprawl and affecting land uses changes. Rapid urbanization becomes virtually synonymous of the city's deterioration with loss open spaces, poverty, slums growth. Kinshasa's city lost progressively its ecological heritage and identity cultural caused by enormous problems. Most of Sub Sahara African cities face similar problems. Kinshasa's city is far from to achieve sustainable urbanization.

\subsubsection{Problems in Basic services and Housing}

Around the world over 1 billion urban residents live in inadequate housing, mostly in slums and squatter settlements, where living conditions are poor and services are insufficient (6). Housing sector has been neglected during a long period, and till now, it is not a prior concern in Democratic Republic of Congo. A great number of 
housing units within Kinshasa's city are not conforming to building regulations. It is particularly difficult for the urban poor to obtain tenure because property registration processes are inefficient, complicated, and expensive. The process is even more difficult in the case of informal settlements. Many governments hesitate to legalize them for fear of encouraging even more illegal settlement (7). Many illegal settlements are built on land poorly suited for housing for instance, on floodplains or on steep hillsides and are especially prone to damage from natural disasters (8).In others terms, urban population often settle on land not suitable for housing located on agricultures areas, open spaces and also in high-risk zones such as steep, public spaces, hill slopes, and deep gullies and flood-prone. As a consequence, insecurity, erosions, floodwaters, landslides, are on increase.

In addition, basic services needed for good health often do not reach the urban poor because municipal authorities do not recognize many informal settlements for political and administrative reasons, and thus these areas are not eligible for services. In some cases, slum areas are not classified as urban precisely because they lack services (9).Inadequate basics services compromise public water supply. This leads populations in Kinshasa's city to use other water sources often unsafe. The needs and priorities in basic services and housing provision do not meet urban people's expectancy for vital services, residences and business establishments.

\subsubsection{Archaic Master plan, Infrastructures and Transport Problems}

\section{Archaic Master plan}

The master plan adopted over colonial period has not produced a satisfactory physical environment. The plan is largely limited to the distribution of land use aspects. It is also disproportionately long in urban development planning process. The old forms of plan lead to social and spatial marginalization; as if to say master plans are obsolete to keep pace with provision of infrastructure, environmental conservation and urban development. Nowadays, the city has not an official city plan in operation. So, a comprehensive city structure, zoning, building control, public utility layouts, and so on, cannot be drawn up. Horizontally, the city is spreading along the new roads. Residential houses are mixed with commercial, industrial buildings and markets, all of various shapes and sizes. Of course, a comprehensive plan of city development cannot be drawn up with an archaic master plan.

\section{Infrastructures and Transport Problems}

The infrastructures originate from colonial times whereas population nowadays is exceeding 10 million people. They have not been maintained to the level necessary to avoid decay. Extending infrastructure such as bridges, buildings, roads and rail lines, sewers, shelters, water mains are now in disrepair. Moreover, new neighborhoods are often developed, without planning to allow space for others infrastructures. There are no major paved roads connecting the regions of the country or virtually non existent and though there are an estimated 157,000 kilometers $(97,560$ miles) of roads in the country, most of them are poorly maintained. It is difficult within city to reach or connect to roads, water and sewage services. This represents a major impediment to economic improvement.

Transport is incontestably a puzzle for millions of Kinshasa's citizens. The deficient public's transport and a large number of poor roads are the factors making harder traffic goods and movement of populations. Despite the weak transport network, the scarce asphalt roads, the bad driving habits of residents in urban areas and the neglect and violation of traffic rules exacerbate the traffic congestion .The illegal parking and lane changing also adds to traffic congestion.

In addition, rainy season transforms Kinshasa immediately in flood (water- flood): the sewers stuffed with rubbish mix with the water, the symbolic roads ruined and plots and electric cable swamp the city. The grater number of people in Kinshasa has to walk in dirty water to back to their homes in this urban area flooded sprawl. This lengthens commuting time. After every heavy rain, landslides sometimes occur the traffic becomes difficult. The prevailing resignation of authorities on management of city supports sense of fears and hopeless, as if to say general insecurity.

\subsubsection{Insufficient Incomes and Food insecurity}

Democratic Republic of Congo (ex Zaire) experienced economic decline with the expulsion of foreign merchants or expropriation of foreign assets expropriation in the plan called zairianization. This plan announced by the former President Mobutu in 1973 was a form of patrimonial, which leads the act of distributing goods and companies to family members and the loyal political members, and army officials. After that, the lootings occurred in Kinshasa fifteen years ago with the loss of companies and services. These events have inextricably complicated and exacerbated the economic crisis and consequently increase informal economic. The falling demands for goods and services puts even more people out of work and have no access to food although it is the largest expense category in the budget. The situation is now worst with the war in the east of country with armed conflict rooted for mineral resources, and the failing state. Majority of urban populations lost jobs and income due to reduced demand for manufactured goods, transport, and other services. The presence of armed groups and global insecurity over many years has weakened food's production. Moreover, the deficits in infrastructures simultaneously compromises and reduces food provisions capacity. In fact; foods, utilities, and essential imported consumer goods become more expensive. Major food producers maintain minimum food reserves because of the unsure political and economic environment, as well as national currency values have fallen and the frequent threats of civil war and political instability. The government leaderships and experts argued that the 
region's economic crisis is particularly harming urban economies.

\subsubsection{Security Problems (crime and violence)}

Security's problems are a complex problem in Democratic Republic of Congo. It is merely a continuation of longstanding problems from different regimes (Mobutu, Kabila's father, and Kabila's son). Of course, the conflict armed in the east that brought a transition government between different rebels group leave a trail of a weak democracy and insecurity. The causes of this war are harsh and rancorous, for that reason, Gavin Williams noted: No regions, and few countries, in Africa have been free of the ravages of civil wars, conflicts between African countries, dictatorial governments, and the intervention of outside powers and other African governments (2002: 10).

Crime and violence increase in Kinshasa where women and children are a vulnerable group in all areas. While a category of urban population turns to break in, fraud, robbery, and violence; women turn to prostitution just to survive. The social context appears to incline violence against women inside what should be the most secure of place. Until now, the new government elected has not control the complex problems of security's that still remain entire. At this time, it is impossible to talk about the effective implementation of integration of populations (especially youth and women into society).Governments (national and local authorities) cannot promote educational, health, and employment, which are basic foundations for inclusive social protection systems. Actually, an emerging area of concern is the rising levels of crime, juvenile delinquency and violence. The prevailing failure to deal with insecurity at the municipal level frequently results in the exacerbation of intra-city tensions, community alienation, erosion of social cohesiveness and corruption.

\subsubsection{Pollutions}

Generally, transport discharge (Petroleum hydrocarbons from automobile, benzene from aircraft and others) causes the pollution of air. Nutrient and bacterial sources of contamination include fertilizer usage for agriculture, pet wastes, leaves, grass clippings, and faulty septic tanks contributing to a variety of water-related diseases. Most of streams in Kinshasa abound pollutants such as sediment, nutrients, oxygen-demanding substances, road salts, heavy metals, petroleum hydrocarbons, pathogenic bacteria, and viruses. Approximately half of these emissions are caused by the burning of fossil fuels for urban transport; the other half comes from energy to heat or cool our buildings and to run our appliances. These are the hallmarks of our built environment and our quest for quality-of-life in urban places which have to inform mitigation and adaptation strategies for climate change.

Furthermore, the noise's pollution is increasing in Kinshasa due to unfettered growth of bars and churches. Noise pollution disturbs residential, social, working .It has profound public health and social implications. The hearing damage is related to the intensity of noise exposure, many people are exposed, and children seem to be more vulnerable than adults. Noise pollution creates interference in communication which leads personal disabilities, handicaps, and behavioral changes.

These include problems with concentration, mental fatigue, uncertainty, lack of self confidence, irritation, misunderstandings, decreased working capacity, disturbed interpersonal relationships, and stress reactions.

Noise pollution affects sleep disturbances. Apart from various effects on sleep itself, noise pollution during sleep causes increased fatigue, depressed mood and well-being, and decreased performance. Combinations of noise and vibration have a significant detrimental effect on health, even at low sound pressure levels .Noise pollution is a contributor to the anxiety, nervousness, nausea, headache, emotional instability, and sexual impotence, changes in mood, increase in social conflicts and negative Social behavior and annoyance reactions stress in urban areas.

\subsubsection{Solid wastes, Electricity and Water}

\section{Electricity and Water}

With rapid urbanization, needs of using electricity and water increase significantly, although shortfall in and electricity freshwater are flagrant within city. However, the weak access to electricity is unequally and irregularly distributed to households, and power cut and disconnection are frequent. Majority of urban population reside in total darkness and are exposed in crime, robbery and violence. Thousands of people choose to get electricity by connecting to principal cable, without laws and previous disposals at their own risk. An anarchic tangle of electricity cables, hidden beneath tarmac, connects the shantytown to metered supplies in the adjoining legal settlement. As consequences, after every downpour fatal danger is frequent. People are exposed in the electrocution fields created by energizing the water with the pending electrical cables.

Furthermore, many urban people have not access to clean water. Fast population growth with accelerated urbanization, combined with scarce water supplies and poor sanitation, means that governments often cannot supply enough water to meet demand (10).In fact, most of residents have water pipes in their homes, but water cannot flows every time, and sometimes when water flows, it is unsafe. Urban water supplies often are contaminated from a variety of sources, including discharge of untreated industrial wastes, leaching from waste dumps into surface and ground water, inadequate treatment of sewage, and poor solid waste management (11).

Solid wastes

In addition, Kinshasa's city crowds steadfast by solid wastes that affect the city's ecosystem. The waste stream 
comes from garbage, which is the principal of all the wastes. Garbage includes rubbish, junk, trash, wastes from household preparation, cooking and serving of food; market refuses handling, storage and sales of produce and meals. No biodegradable solid waste or rubbish (such as cardboard, ceramics, container, clothes, paper, plastics, package , rubber, leather bottles, glass, tin cans, and so on) is also generated within city. There are other sources that include ashes, bulky waste, street sweeping, abandoned vehicles, non-hazardous industrial waste, construction and demolition waste etc. A particular feature of solid waste in Kinshasa is imported second hand goods from the developed world.

Everywhere within city, suspended sediments drive mass of pollutant loadings to receive waters solid wastes. Most of the anaerobic canals and waterways filled with mud, sand or rubbish, leading to recurrent floods and give off the offensive smells. Residences and industries discharge wastewater straight into storm drains that directly connect to those canals or waterways that threaten the quality of urban life by causing chronic diseases (cholera, malaria, typhoid fever etc.).

\section{Weak implications of government}

The weak implication of government leadership is the direct outcome of immature and unwilling political system; unfortunately the fact is repercussive in urban planning sectors yet. They lack powers required for effective strategies development, particularly in such critical areas as investment in urban infrastructure, service delivery, revenue generation, and promoting urban economic development. The situation limits capacity to bring legal frameworks and public agencies to deal with urban problems at local and national levels. Urban planning field is not a prior concern. Substantial financial in this come from internationals organisms. This confirms the weak implication of authorities, for that reason urban sectors are defective. The balance of power and distribution of functions between national, provincial and local governments is more complex and not positively evolving.

There is no clarity as to which sphere of government national, provincial or even local should proceed with the reform of this legal framework and the design of one more suited to current needs and conditions. Perhaps, because of urban sectors paid the lack of funds. There are no plans, guidelines, techniques, and suggestions on how to understand and solve the urban problems. Despite the importance of urban economic growth in national development, there are not the policy and institutional framework for managing urban growth in Democratic Republic of Congo. As a result, the surrounding environment suffers for example, through the unsanitary disposal of wastes and air and water pollution (12).

The city's development dynamism depends on it in order to integrate the needs and wants of the population in growing without the expense of environmental quality. It is revealed complex problems of rapid urbanization, not because the process is bad, but because the progress occurs without consideration for ecology and land use management. One powerful way for restoring and fostering urban sustainability is through the field of urban planning. In this context, the decision in its whole refers to the dynamics of management, qualification and transformation of the city, and is therefore distinct from the intervention of architecture or civil engineering. This leaves a reform in governance path to the critical role that urban planning must play in ensuring urbanization. An emerging international consensus says that; good governance is a crucial prior condition for poverty eradication.

\section{Reform in governance}

Democratic Republic of Congo is experiencing crisis that reach its paroxysm. National economic decrease cannot boast high level of urban development; high standards of health, life expectancy or education in urban areas. However, the government's budget is not distributed equally mainly due to differentiation in all sectors. For example mines sector with higher income has higher income and therefore will obviously have a higher budget to work with at the expense educational sector.

Urban areas are usually negligent in the financial department. Therefore, it is difficult to cope with all the problems in which need to be fixed in city, such as education sanitation, transport, and many other categories. A wide a range of experts (ecologists, civil engineers, geographers, sociologists, urban planners, and policy makers) and common man become aware of this dramatic situation compromising sustainable urbanization.

At this beginning of the $21^{\text {st }}$ century, the hope to see sustainability in Democratic Republic of Congo depends on the reform in political and institutional structures. The reform seeks to position decentralization in performing governance in all development sectors. It must encourage active participation and agreement between all actors.

The change in governance reflects the management of human resources, assurances funds support for development. Governments (central and local) should take on a more responsibilities to promote development strategies and ensure attempting to meet demands for education, housing, agriculture and industrial development, transportation and employment. Governments, both national and local must understand and determine the informal sector and ensure that urban planning systems respond positively to this phenomenon, including through legislation. The reform in urban sectors requires an appraisal of urban planning systems.

This must clearly address a number of major current and emerging urban challenges, especially climate change, rapid urbanization, poverty, informality and safety. The reform leads to reconsider rapid urbanization in global age based on an integrating vision of urban issues, where the technical, economic and sociological components are articulated. 
So, central government should provide local governments with sufficient resources and autonomy to support urbanization. In this sense, the new configuration of planning systems is crucial to identify advantages and disadvantages which can be built on or which can compromise planning institutions.

In addition, decentralization as an integral part of reform supports an effective management at local level with technical staff qualified to understand and determine sustainable development of cities and societies. It makes easy the administration in small urban communities, maintaining economic and ecologic viability. It is important to rethink urbanization process as a creator factor of resource economics. So, urban local policymakers should formulate infrastructure plans as central elements of strategic spatial plans with the participation of local populations (urban poor people are the social group more concerned, and most affected by urbanization). The reform in governance intends the effective participatory mechanisms for socially marginalized groups. Any action requires prior consultation with all part stakeholders. Planning and land management agencies have numerous and varied responsibilities and tasks (Jensen and Cowen, 1999). So, the evaluation should concentrate on the implementation of site, subdivision and neighborhoods plans. The reform advocates a global vision for a collective commitment at local or national level with evidence.

But, the reform in governance is on the beginning in Democratic Republic of Congo. Kinshasa's city has always been an important role for the country's development and for social integration. It was an engine of growth, more convenience, educational and sports facilities, health care system, security. It should be advisable to regenerate habitat and heritage cultural continuity, and quality of life of yesteryears. The government leaderships should invest to put back order as it expects economic, political and social progress in the forefront of global socio-economic change, and urban poverty in urban areas. It belongs to reinforce the capacity of experts to adopt appropriated urban planning, which decisions should be given very high priority and developed on the basis of realistic standards.

\section{Challenge of Sustainable Urbanization}

Sustainable development has been defined as development that meets the needs of the present without compromising the ability of future generations to meet their own needs (World Commission on Environment and Development, 1987). Nowadays, the concept of sustainable development is applied to the field of urban planning. Sustainable urbanization projects a positive vision to create stability between the built and the natural environment while ensuring social, economic and ecology development. Urban planning decision in its whole refers to the dynamics of management, qualification and transformation of the city. Importantly, urban planning offers methods adapted for countries experiencing different levels of social economic development, and different forms of urbanization. The success to achieve sustainable urbanization needs absolutely acting on lessons learned from experience in the city and elsewhere. From now, it becomes possible to talk about sustainable urbanization with community involvement, and to meet the international goal of reducing poverty by half in 2015. This requires adopting pragmatic approaches.

- A new approach for new master plan. The master plan is a design for the physical, social, economic and political framework for the city, which contributes deeply to the quality of urban governance city and help location place within city. The strategic spatial plan linked to infrastructure development promotes more compact forms of urban expansion focused around accessibility and public transport. It give a sense of urban services, urban local authorities to make infrastructure plans as key elements of strategic spatial plans that can facilitate the sustainable expansion of cities. The urban planning includes spatial structure of city and infrastructures. As a result, Kinshasa's city can be redesigned to preserve cultural continuity, heritage and natural environment of city. The preservation of open spaces, especially green areas, is necessary to sustainable development in urban regions (Ward Thomson, 2002).Plan land use is essential to sustainability,

- A new approach to apply information technology in urban planning. Information technology reinforces accurate assessment and monitoring for better urban governance. Remote Sensing (RS) and Geographic Information System (GIS) give orientations to control urban sprawl and ecosystem management. It is important to understand and evaluate urban sprawl impacts on demographic, environment, infrastructures, and urban areas. Information technology (GIS and RS) provide the basis for estimating and mapping risk, for planning evacuation routes and shelters, for determining areas where human populations are most likely to have been impacted following risks (erosions, floodwaters, landslides), and for assigning resources during recovery, among many other vital and important tasks. Open spaces and agricultures areas become a resource in short supply in Kinshasa. The public's spaces disappear with overcrowding in inner city. Land uses changes become a principal component in common strategies for managing natural resources and monitoring environmental changes. It is useful to determine and evaluate rapid urbanization involving Geographic Information System (GIS) and remote sensing (RS). Urban planning systems should integrate monitoring and evaluation as permanent features for solutions to the present and future urban development.

- A new approach for a commitment collective. This innovative approach requires an active participation of stakeholders in the planning process. This concern governments (central, province and city municipality), research institutes and academics, non-government organizations, and communities participatory to create and maintain efficient infrastructures and security; to guarantee education, employment, health, access to transport, that is to say improve the quality of life, community, mobility, environment; and the conservation of natural 
areas.

- A new approach for teaching Urban Planning. It is urgent to prepare students to work in different world contexts by adopting the genuine approach adequate to for the country's or region's realities.

\section{Conclusion}

Beyond complex problems for urban development, for which the governments are unable to deal with, rapid urbanization should completely turn into sustainable urbanization in order to offer opportunities to change positively cities in Democratic Republic of Congo. From now, it is important to articulate and strengthen the dynamics of management, qualification, rehabilitation or renovation in order to achieve sustainable growth. Comprehensive planning should reassess the management of natural resources and would deal with demographic, economic, environmental and social problems.

The reform refers to the good governance, should adapt the regulation on lands uses changes and spatial inequalities. It calls for improving the long-term balanced economical growth activity, human development and ecological health that rapid urbanization entails. Urbanization will be sustainable as long as there are sufficient economic resources to finance the technological research and development strategies needed to transform the natural environment so that it will meet human needs. However, the successful implementation of sustainable urbanization requires a fortiori the willing and obligation from national and local governments to support adequate funds, but also the active public's participation. Today, the urgent appeal is launched to adopt urban renewal for the Kinshasa's city's suffering infrastructures decay. So, the city will become viable for future generations.

\section{References}

Allen, J. and C. Hammett. (1988). A Shrinking World? Global Unevenness and Inequality, Oxford: Oxford University Press.

Aston, T.H. and Philpin, C.H.E., eds. (1985). The Brenner Debate: Agrarian Class Structure and Economic Development in Pre-Industrial Europe. Cambridge: Cambridge University Press.

Amis, Philip. (1995). "Making Sense of Urban Poverty", Environment and Urbanization, Vol. 7, No.1, pp. 145-157.

Attahi, Kofi. (1989). “Cote d'Ivoire: An evaluation of urban management reforms", in R. Stren and R. White (eds.), African Cities in Crisis, Boulder: Westview Press, pp.112-146.

Baker, Jonathan. (1992). Small Towns in Africa, Uppsala: Scandinavian Institute of African Studies.Bartone, C.and J.Bernstein et al., 199, Toward environmental strategies for cities: Policy considerations for urban environmental and management in developing countries. The World Bank, Washington

Economist. (2000). Life in Kinshasa. 64. ISSN 0013-0613.

Encyclopedia Britannica. Kinshasa. Retrieved August 4, 2008.

Eldon D.Enger, Bradley F., Smith Anne, Todd Bockarie. (2007). Environmental Science A Study of Interrelationships, Tenth Edition, 1.2007.

Gugler, Josef. (1996). Urbanization in Africa South of the Sahara: New Identities in Conflict. The Urban Transformation of the Developing World, edited by Josef Gugler. Oxford: Oxford University Press.

UNESCO. (1990). Report of the International Symposium and Round Table, Qualities Required of Education Today to Meet Foreseeable Demands in the Twenty-First Century. Beijing People's Republic of China, UNESCO, Paris.

United Nations Development Programme (UNDP). (2001). Human Development Report: Making New Technologies Work for Human Development. New York and Oxford: Oxford University Press.

Wilkipedia, the free encyclopedia: Goodall, B. (1987). The Penguin Dictionary of Human Geography. London: Penguin.

Williams, Gavin. (2002). "Reforming Africa: Continuities and Changes." Africa South of the Sahara 2003 (32nd edition). London: Europa Publications.

World Population Prospects: The 2008 Revision. Highlights. New York: United Nations. Population Division of the Department of Economic and Social Affairs of the United Nations Secretariat (2009).

Zeng L. and Ma, S. H. (2003). Progress of the Innovation of Land Requisition System in the Urbanization Process, Information on State Land and Resources, 9: 1-8.

Zhang, G. R. and Gu, Ch. L. (2006). Passive Urbanization in Rapid Urbanization, City Planning Review, 30(5): 48-54.

Zhang, H. L. (2006). Economic Analysis of the Land Requisition System in Urbanization, Shanghai Economic Research, 3:6-16.

Notes

Note 1: World Urbanization Prospects: The 2007 Revision, Pop. Division, Department of Economic and Social Affairs, United Nations. 
Note 2. Global Commission on International Migration, Migration in an Interconnected World: New Directions for Action," (2005) p. 11).

Note 3. Wilkipedia, the free encyclopedia: Goodall, B. (1987) The Penguin Dictionary of Human Geography. London: Penguin.

Note 4. Eldon D.Enger Bradley F. Smith Anne Todd Bockarie, Environmental Science, A Study of Interrelationships, Tenth Edition 284.

Note 5. For detailed data, UNFPA June 2007 and UN Population Division "World Urbanization Prospects"2006. Note 6. UNITED NATIONS CENTRE FOR HUMAN SETTLEMENTS (HABITAT). The state of the world's cities 2001. Nairobi, UNCHS, 2001. 125 p.

Note 7. SOLO, T.M., PEREZ, E., and JOYCE, S. Constraints in providing water and sanitation services to the urban poor. Washington, D.C., Water and Sanitation for Health (WASH) Project, Mar. 1993. (WASH Technical Report No. 85) 32p.

Note 8. BAHAROGLU, D. and KESSIDES, C. Urban poverty technical notes. In: Poverty Reduction Strategy Paper (PRSP) Sourcebook. Washington, D.C., World Bank, Apr. 2001. 49p.

Note 9. BEIJING CORRESPONDENTS. Nearly $20 \mathrm{~m}$ in extreme poverty. Herald Sun. (Melbourne, Australia), Jan. 4, 2003.(Available: http://www.heraldsun.news.com.au/common/

story_page/0,5478,5796610\%255E401,00.html>, Accessed Jan. 16, 2003)

Note 10. WHO/UNICEF JOINT MONITORING PROGRAMME FOR WATER SUPPLY AND SANITATION. Global water supply and sanitation assessment 2000 report. Geneva, World Health Organization (WHO) and United Nations Children's Fund (UNICEF), Apr. 24, 2001. 79 p. (Available: <http://www.who.int/water_s a n i $\mathrm{t}$ a $\mathrm{t}$ i o $\mathrm{n}_{-} \mathrm{h}$ e a $1 \mathrm{th}$ / Globassessment/Glasspdf TOC. htm>, Accessed Oct. 14, 2002)

Note 11. BICEGO, G. and AHMAD, O.B. Infant and child mortality. Calverton, Maryland, Macro International, Aug. 1996. (Demographic and Health Surveys Comparative Studies No. 20)

Note 12. BEIJING CORRESPONDENTS. Nearly 20m in extreme poverty. Herald Sun. (Melbourne, Australia), Jan. 4, 2003.(Available: http:/www.heraldsun.news.com.au/common/ story_page/0,5478,5796610\%255E401,00.html>, Accessed Jan. 16, 2003)

Table 1.

\begin{tabular}{|c|c|c|c|c|c|c|c|c|c|}
\hline \multirow[b]{2}{*}{ Major area } & \multicolumn{5}{|c|}{$\begin{array}{c}\text { Population } \\
\text { (millions) }\end{array}$} & \multicolumn{4}{|c|}{$\begin{array}{l}\text { Average anmual rate of change } \\
\text { (percentage) }\end{array}$} \\
\hline & 1950 & 1975 & 2007 & 2025 & 2050 & $\begin{array}{c}1950- \\
1975\end{array}$ & $\begin{array}{l}1975- \\
2007\end{array}$ & $\begin{array}{c}2007- \\
2025\end{array}$ & $\begin{array}{c}2025- \\
2050\end{array}$ \\
\hline \multicolumn{10}{|l|}{ Total population } \\
\hline Africa & 224 & 416 & 965 & 1394 & 1998 & 2.48 & 2.63 & 2.04 & 1.44 \\
\hline Asia & 1411 & 2394 & 4030 & 4779 & 5266 & 2.12 & 1.63 & 0.95 & 0.39 \\
\hline Europe & 548 & 676 & 731 & 715 & 664 & 0.84 & 0.24 & -0.12 & -0.30 \\
\hline Latin America and the Caribbean & 168 & 325 & 572 & 688 & 769 & 2.65 & 1.77 & 1.02 & 0.45 \\
\hline Northern America & 172 & 243 & 339 & 393 & 445 & 1.40 & 1.03 & 0.82 & 0.50 \\
\hline Oceania & 13 & 21 & 34 & 41 & 49 & 2.03 & 1.49 & 1.05 & 0.65 \\
\hline \multicolumn{10}{|l|}{ Urban population } \\
\hline Africa & 33 & 107 & 373 & 658 & 1234 & 4.76 & 3.90 & 3.15 & 2.52 \\
\hline Asia & 237 & 574 & 1645 & 2440 & 3486 & 3.54 & 3.29 & 2.19 & 1.43 \\
\hline Europe & 281 & 444 & 528 & 545 & 557 & 1.84 & 0.54 & 0.18 & 0.08 \\
\hline Latin America and the Caribbean & 69 & 198 & 448 & 575 & 683 & 4.21 & 2.55 & 1.38 & 0.69 \\
\hline Northern America & 110 & 180 & 275 & 337 & 401 & 1.98 & 1.33 & 1.11 & 0.70 \\
\hline Oceania & 8 & 15 & 24 & 30 & 37 & 2.60 & 1.44 & 1.17 & 0.89 \\
\hline \multicolumn{10}{|l|}{ Rural population } \\
\hline Africa & 192 & 309 & 592 & 736 & 764 & 1.92 & 2.03 & 1.21 & 0.15 \\
\hline Asia & 1174 & 1820 & 2384 & 2339 & 1780 & 1.75 & 0.84 & -0.11 & -1.09 \\
\hline Europe & 267 & 232 & 204 & 170 & 107 & -0.57 & -0.41 & -1.00 & -1.84 \\
\hline Latin America and the Caribbean & 98 & 126 & 124 & 113 & 87 & 1.01 & -0.06 & -0.50 & -1.08 \\
\hline Northern America & 62 & 64 & 63 & 56 & 44 & 0.11 & -0.02 & -0.65 & -1.00 \\
\hline
\end{tabular}

Source: United Nations Department of Economic and Social Affairs/Population Division 3 World Urbanization Prospects: The 2007 Revision 
Table 2. Population of major cities (2008)

\begin{tabular}{|l|l|}
\hline City & Population (2008) \\
\hline Kinshasa & 7.500 .000 \\
\hline Mbuji Mayi & 2.500 .000 \\
\hline Lubumbashi & 1.700 .000 \\
\hline Kananga & 1.400 .000 \\
\hline Kisangani & 1.200 .000 \\
\hline Kolwezi & 1.100 .000 \\
\hline Mbandaka & 850.000 \\
\hline Likasi & 600.000 \\
\hline Boma & 600.00 \\
\hline
\end{tabular}

Source: From Wikipedia, the free encyclopedia, Democratic Republic of Congo.

Table 3. Democratic Republic of the Congo Population (thousands) Medium variant 1950-2050

\begin{tabular}{|l|l|l|l|}
\hline Year & Population & Year & Population \\
\hline 1950 & 12.184 .000 & 2005 & 59.077 .000 \\
\hline 1955 & 13.589 .000 & 2010 & 67.827 .000 \\
\hline 1960 & 15.385 .000 & 2015 & 77.419 .000 \\
\hline 1965 & 17.504 .000 & 2020 & 87.640 .000 \\
\hline 1970 & 20.285 .000 & 2025 & 98.123 .000 \\
\hline 1975 & 23.433 .000 & 2030 & 108.594 .000 \\
\hline 1980 & 27.170 .000 & 2035 & 118.882 .000 \\
\hline 1985 & 31.402 .000 & 2040 & 128.907 .000 \\
\hline 1990 & 37.016 .000 & 2045 & 138.525 .000 \\
\hline 1995 & 44.921 .000 & 2050 & 147.512 .000 \\
\hline 2000 & 50.829 .000 & \multicolumn{2}{|l}{} \\
\cline { 1 - 2 } & &
\end{tabular}

Table 4. Demographic Evolution of Kinshasa

\begin{tabular}{|l|l|l|l|}
\hline Years & Inhabitants & Years & Inhabitants \\
\hline 1920 & 1600 & 1970 & 1.323 .039 \\
\hline 1936 & 40.300 & 1974 & 1.990 .700 \\
\hline 1938 & 35.900 & 1976 & 2.443 .900 \\
\hline 1939 & 42.000 & 1984 & 2.664 .309 \\
\hline 1947 & 126.100 & 1991 & 3.804 .000 \\
\hline 1957 & 299.800 & 1994 & 4.655 .313 \\
\hline 1959 & 402.500 & 2003 & 6.786 .000 \\
\hline 1967 & 901.520 & 2005 & 7.500 .000 \\
\hline 1968 & 1.052 .500 & 2015 est. & 12.000 .000 \\
\hline
\end{tabular}

World Gazetteer, Africa: largest cities and towns and statistics of their population. Retrieved August 7, 2008. 


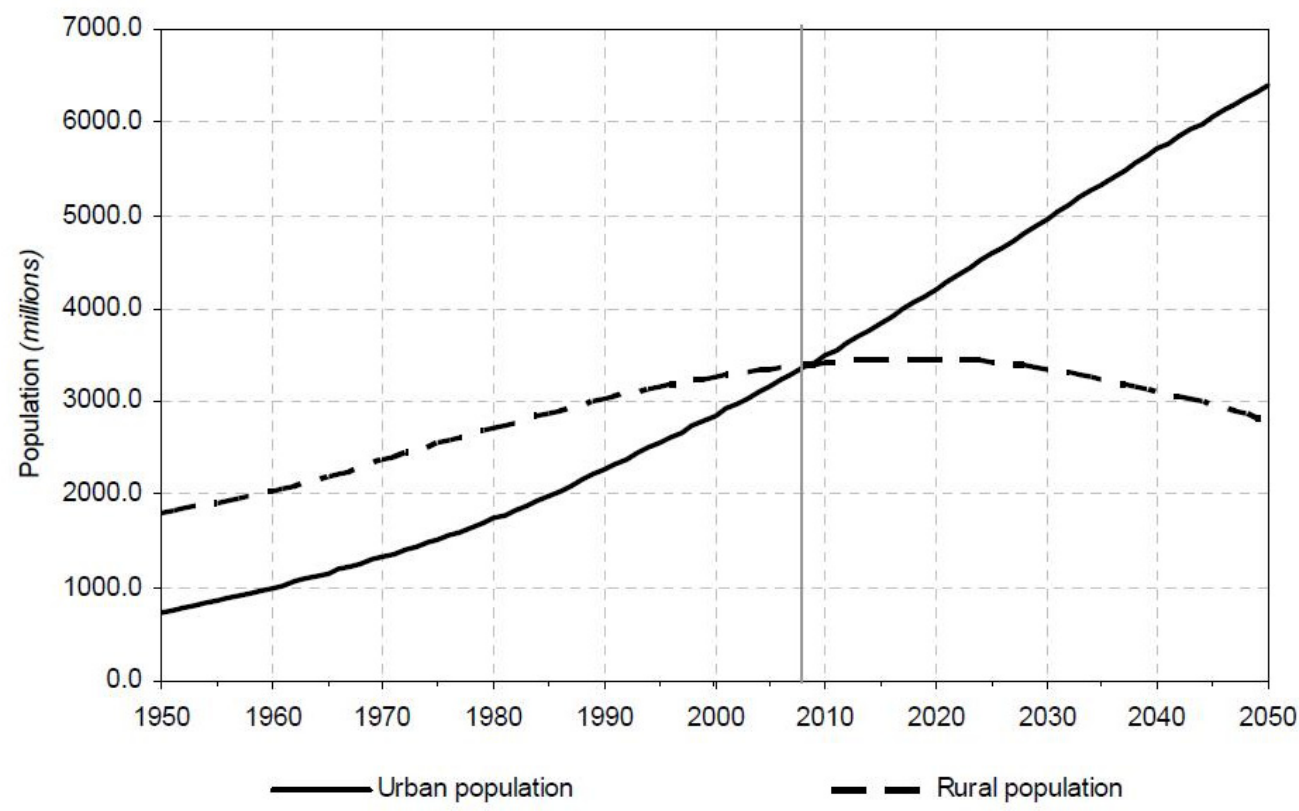

Figure 1. Urban and rural populations of the world 1950-2050

Source: United Nations Department of Economic and Social Affairs/Population Division 3 World Urbanization Prospects: The 2007 Revision

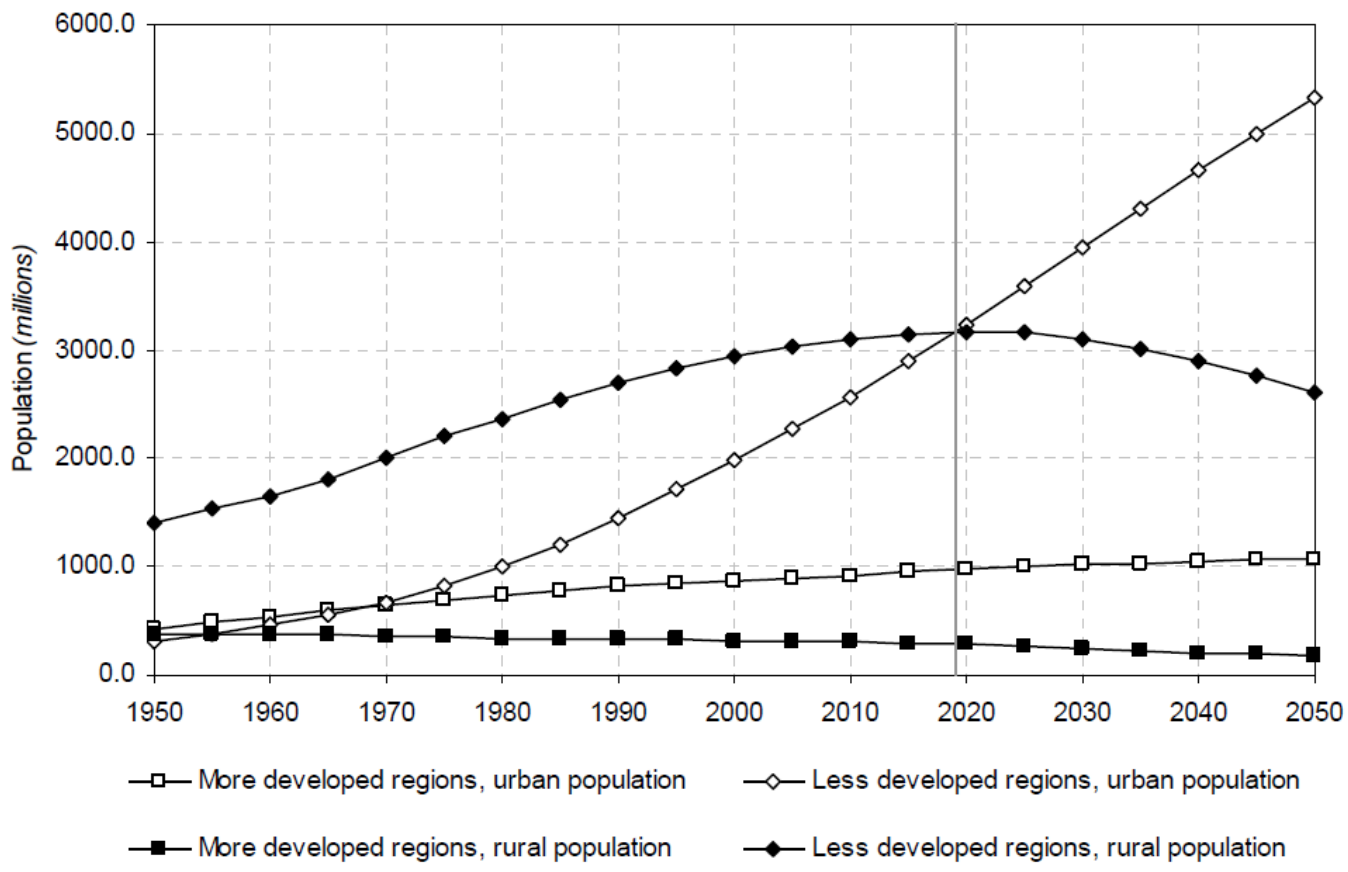

Figure 2. Urban and rural populations, by development group, 1950-2050.

Source: United Nations Department of Economic and Social Affairs/Population Division 3 World Urbanization Prospects: The 2007 Revision 


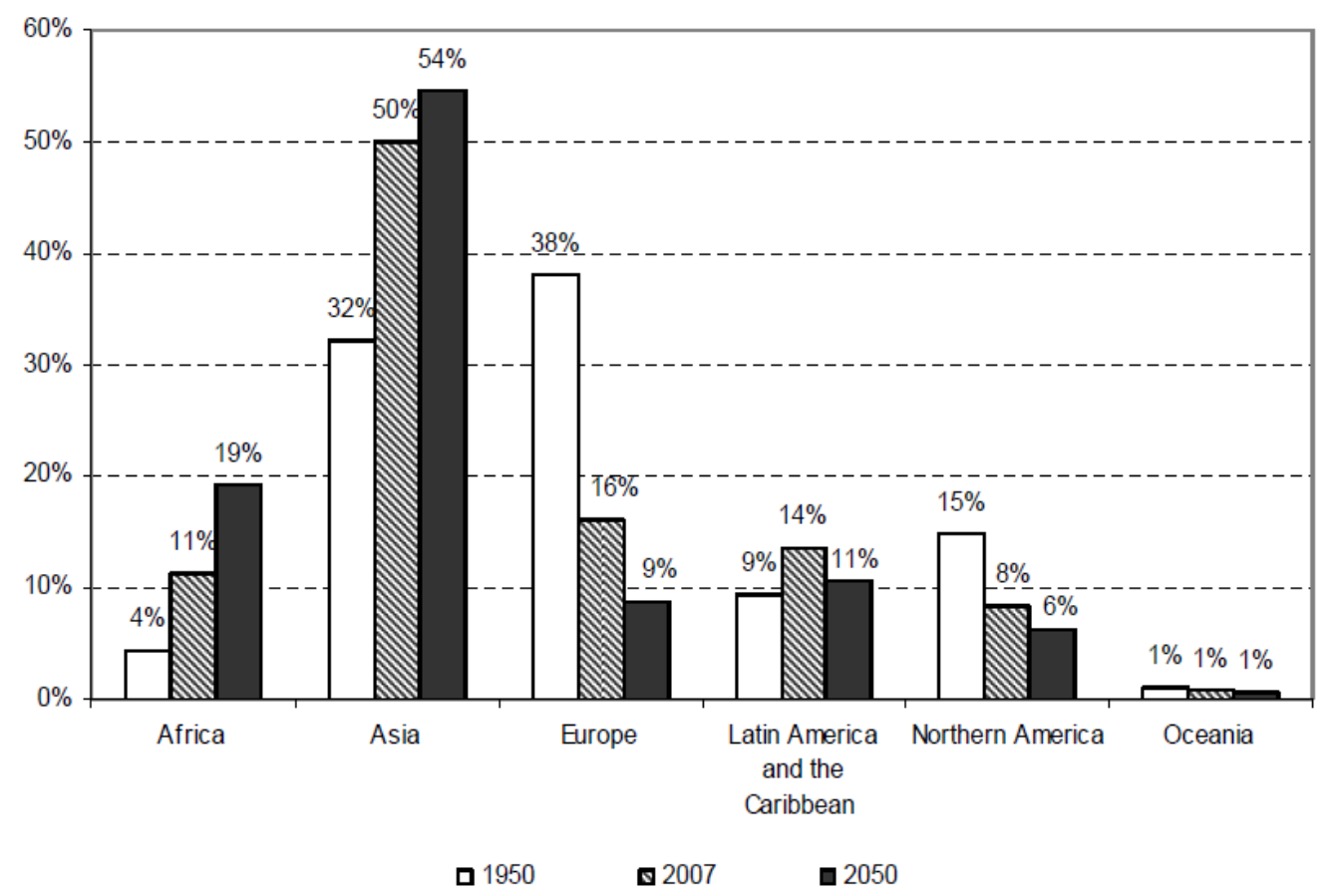

Figure 3. Distribution of the world urban population by major area, 1950, 2007, 2050

Source: United Nations Department of Economic and Social Affairs/Population Division 3 World Urbanization Prospects: The 2007 Revision 